\title{
Effects of Fifty-Hertz Electromagnetic Fields on Granulocytic Differentiation of ATRA-Treated Acute Promyelocytic Leukemia NB4 Cells
}

\author{
Alfredo Errico Provenzano ${ }^{a}$ Stefano Amatoria ${ }^{a, b}$ Maria Gemma Nasoni ${ }^{a}$ \\ Giuseppe Persico ${ }^{a}$ Sergio Russo ${ }^{a} \quad$ Anna Rita Mastrogiacomo ${ }^{c}$

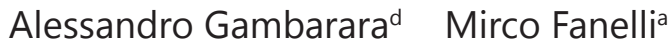

aniversity of Urbino, Molecular Pathology Lab. "PaoLa", Department of Biomolecular Sciences, Fano, ${ }^{b}$ European Institute of Oncology, Department of Experimental Oncology, Milan, ${ }^{\prime}$ University of Urbino, Section of Biotechnology, Department of Biomolecular Sciences, Fano, dUniversity of Urbino, Electromagnetic Fields Laboratory, Department of Pure and Applied Sciences (DiSPeA), Urbino, Italy

\section{Key Words}

Acute Promyelocytic Leukemia (APL) - ELF-EMF - Granulocytic differentiation - Reactive Oxygen Species (ROS) • ERK1/2

\begin{abstract}
Background/Aims: Life on Earth is constantly exposed to electromagnetic fields (EMFs) and the effects induced by EMFs on biological systems have been extensively studied producing different and sometimes contradictory results. Extremely low-frequency electromagnetic fields (ELF-EMFs) have shown to play a role in regulating cell proliferation and differentiation, although how EMFs influence these processes remains unclear. Human acute promyelocytic leukemia (APL) cells are characterized by the arrest of differentiation at the promyelocytic stage due to epigenetic perturbations induced by PML/RAR $\alpha$ fusion protein (Promyelocytic Leukemia protein - PML / Retinoic Acid Receptor alpha - RAR $\alpha$ ). Therapeutic administration of all-trans retinoic acid (ATRA) re-establishes the leukemogenic mechanism re-inducing the normal differentiation processes. Methods: We studied the effects of ELF-EMFs $(50 \mathrm{~Hz}, 2$ $\mathrm{mT}$ ) on the ATRA-mediated granulocytic differentiation process of APL NB4 cells (a cell line established from the bone marrow of a patient affected by the acute promyelocytic leukemia) by monitoring cellular proliferation and morphology, nitroblue tetrazolium (NBT) reduction and the expression of differentiation surface markers. Finally, we investigated mechanisms focusing on reactive oxygen species (ROS) generation and related molecular pathways. Results: ELFEMF exposure decreases cellular proliferation potential and helps ATRA-treated NB4 cells to mature. Furthermore, the analysis of ROS production and the consequent extracellular signal
\end{abstract}

A. Errico Provenzano and S. Amatori contributed equally to this work

Prof. Mirco Fanelli

KARGER
Molecular Pathology Laboratory "PaoLa", Department of Biomolecular Sciences University of Urbino "Carlo Bo", Arco d'Augusto, 2 - 61032 Fano (PU) (Italy)

Tel. +39 0722 304951, Fax +390722 304970, E-Mail mirco.fanelli@uniurb.it 
regulated kinases (ERK1/2) phosphorylation suggest that a changed intracellular oxidative balance may influence the biological effects of ELF-EMFs. Conclusions: These results indicate that the exposure to ELF-EMF promotes ATRA-induced granulocytic differentiation of APL cells.

(C) 2018 The Author(s)

Published by S. Karger AG, Basel

\section{Introduction}

Environmental exposure to extremely low frequency electromagnetic fields (ELFEMFs) has progressively increased in developed countries due to the distribution and use of electricity [1]. In recent decades, the scientific community has extensively investigated the possible effects of ELF-EMFs on biological systems both in vitro and in vivo [2-6]. Some epidemiological studies offered evidence of a correlation between exposure to ELF-EMFs and increased incidence of brain, breast and haematological malignancies, but these results have not been confirmed by other studies [7-9]. Experiments on animal models similarly produced inconclusive or contradictory results, probably due to the small number of animals examined and the lack of properly standardised exposure parameters [10,11]. Several in vitro studies explored the potential effects of ELF-EMFs on cell proliferation [12], apoptosis $[13,14]$, differentiation [15], genotoxicity [16] and proto-oncogene modulation [17-19] but the results remain open to debate.

Additionally, it is unclear how ELF-EMFs would affect cellular behaviour. A plausible and interesting hypothesis is that they may interfere with chemical reactions involving reactive oxygen species (ROS) production [1]. ROS are not only injurious for cellular structures but also essential to cell signalling. At high levels ROS can lead to impaired cellular physiological function through damage of DNA, proteins, phospholipids and other macromolecules [20]. Conversely, at low levels, ROS can alter intracellular redox states activating redox-sensitive pathways [21,22], including mitogen-activated protein kinase (MAPK) pathway.

Considering the extensive evidence linking ELF-EMFs exposure to haematopoietic alterations $[7,8,23,24]$, we focused on the role of ELF-EMFs in the proliferation and differentiation of acute promyelocytic leukemia (APL) cells, a model not yet investigated. APL (FAB M3) is a type of acute myeloid leukemia (AML) [25] and accounts for $5 \%$ to $10 \%$ of all AML cases. More than $90 \%$ of APL cases has t(15;17) chromosomal translocation which generates the PML-RAR $\alpha$ fusion gene and the consequent accumulation of undifferentiated promyelocytes [26]. Paradoxically, the PML-RAR $\alpha$ protein contributes both to blocking promyelocytes differentiation and to APL blasts sensitivity to the differentiating action of alltrans retinoic acid (ATRA) [27]. At pharmacological doses, ATRA binds PML-RAR $\alpha$ through the RAR $\alpha$ ligand-binding domain, changing the conformation, releasing transcriptional corepressor and recruiting transcriptional co-activators. This allows PML-RAR $\alpha$ to activate transcription of its target genes, re-establishing cellular differentiation [28-30].

In this study, we evaluated the effects of $50 \mathrm{~Hz}$ ELF-EMFs on proliferation and differentiation in the human APL NB4 cell line focusing on the possible involvement of pathways that can be linked to ROS production.

\section{Materials and Methods}

\section{ELF-EMFs system}

The ELF-EMF exposure system was provided by Electromagnetic Fields Laboratory of the Department of Pure and Applied Sciences (University of Urbino) and consists of a cell incubator with a solenoidal type conductor that has 184 enamelled copper coils. The conductor generates a magnetic field at $50 \mathrm{~Hz}$. The cellular exposure was monitored by a specific electromagnetic field measurer (Wandel \& Goltermann EFA200). During exposure, the incubator temperature was maintained at $37.0 \pm 0.1^{\circ} \mathrm{C}$.

\section{KARGER}




\section{Cellular Physiology Cell Physiol Biochem 2018;46:389-400

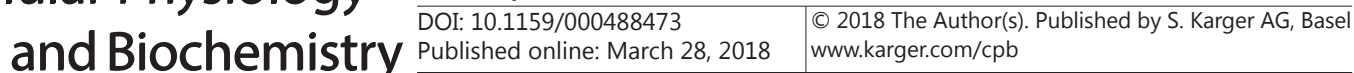 \\ Errico Provenzano et al.: ELF-EMFs Promote ATRA-Induced NB4 Cell Differentiation}

Cell cultures, treatments and cell proliferation estimates

Immortalised acute promyelocytic leukemia (NB4) human cells were cultured in RPMI 1640 medium (Lonza) supplemented with $10 \%$ (v/v) foetal bovine serum (Gibco), 1\% penicillin-streptomycin and 1\% L-glutamine (Gibco) in a humidified atmosphere at $37^{\circ} \mathrm{C}[31,32]$.

NB4 cellular differentiation was induced by $1 \mu \mathrm{M}$ ATRA (Sigma-Aldrich) or $0.16 \mathrm{nM}$ of 12-0-Tetradecanoylphorbol 13-acetate (TPA) for 4 days. Cells were simultaneously exposed to continuous sinusoidal ELF-EMF $(F=50 \mathrm{~Hz})$ at different intensities. ROS scavenging was performed by pre-treating cells for $1 \mathrm{~h}$ with $2.5 \mathrm{mM} \mathrm{N}$-acetylctsteine (NAC). After treatments, cell proliferation was evaluated using a Trypan blue dye exclusion assay with a TC10 automatic cell counter (Bio-Rad).

\section{May-Grünwald-Giemsa staining}

ATRA and PMA-treated cells were stained with May-Grünwald solution (Merck) for $2 \mathrm{~min}$, rinsed with distilled water and stained with Giemsa ( $0.4 \%$ solution in methanol; Sigma-Aldrich) for $10 \mathrm{~min}$. Slides were rinsed thoroughly with distilled water and air-dried. Cell morphology was observed using light microscopy.

\section{FACS Analysis}

The expression of CD11b and CD14 differentiation markers was evaluated by FACS analysis. About 5 $\times 10^{5}$ cells were harvested, washed with $1 \mathrm{~mL}$ of PBS/1\%BSA solution, and incubated for $30 \mathrm{~min}$ at $+4^{\circ} \mathrm{C}$ with the following antibodies: anti-CD11b (clone Leu TM-15; Becton Dickinson) and anti-CD14 supernatant (hybridoma clone UCHM1, provided by Professor Pier Giuseppe Pelicci of the European Institute of Oncology in Milan, Italy).

Cells were washed once in $1 \mathrm{~mL}$ of PBS/1\%BSA solution, incubated with the FITC-conjugated goat anti-mouse antibody (\#62-6511, Thermo Fisher Scientific) at room temperature (light protected) for $30 \mathrm{~min}$ and washed three times. Cells were resuspended in $0.5 \mathrm{~mL}$ of PBS and then analysed for relative fluorescence intensity. Mean fluorescence intensity, determined over 10, 000 events, was analysed on a PAS flow cytometer (Partec).

\section{NBT Assay}

The NBT assay was performed as already described [33]. Briefly, $200 \mu \mathrm{l}$ of cell suspension $\left(5 \times 10^{4}\right.$ cells) were mixed with an equal volume of filtered $0.2 \%$ NBT solution (Sigma-Aldrich) and $3 \mu \mathrm{l}$ of $1 \mu \mathrm{M}$ TPA solution then incubated (light protected) for $30 \mathrm{~min}$ at $37^{\circ} \mathrm{C}$. Subsequently, slides were prepared by centrifugation at $900 \mathrm{rpm}$ for $4 \mathrm{~min}$ and the share of NBT positive cells percentage was determined by scoring 200 cells under a light microscope.

\section{Real-Time RT-qPCR}

Total RNA was extracted from treated or untreated NB4 cells using RNeasy Mini Kit (Qiagen) and reverse transcribed into cDNA using the SuperScript@ First-Strand Synthesis System (Invitrogen).

The cDNA was then combined using FastStart SYBR Green Master Mix (Roche) and the following primers: GAPDH forward: 5'-GCAAATTCCATGGCACCGT-3'; GAPDH reverse: 5'-TCGCCCCACTTGATTTTGG-3'; CD11b forward: 5'-CCTGGTGTTCTTGGTGCCC-3'; CD11b reverse: 5'-TCCTTGGTGTGGCACGTACTC-3'.

Real-time qPCR assays and subsequent data collection used a Rotor-Gene 6000 robocycler (Corbett Life Science). Expression levels of target genes were normalised to that of glyceraldehyde 3-phosphate dehydrogenase (GAPDH), and the relative quantification analysis was based on the $2^{-\Delta \Delta \mathrm{Ct}}$ method [34].

Thermal cycling parameters for Real-Time qPCR were: 1 cycle at $95^{\circ} \mathrm{C}$ for $5 \mathrm{~min}$ and 40 cycles at $95^{\circ} \mathrm{C}$ for $15 \mathrm{sec}$ and $60^{\circ} \mathrm{C}$ for $1 \mathrm{~min}$.

\section{Determination of ROS generation}

The intracellular production of ROS was determined by measuring the oxidative conversion of cellpermeable 2',7'-dichlorofluorescein diacetate (DCFDA) into fluorescent dichlorofluorescein (DCF). Cells were incubated with $20 \mu \mathrm{M}$ DCFDA at $37^{\circ} \mathrm{C}$ for $30 \mathrm{~min}$ in the dark and subsequently treated as indicated. DCF fluorescence intensity was evaluated on a PAS flow cytometer (Partec) and the incremental production of ROS was expressed as fold respect to control not exposed to ELF-EMF. 
Western blot analysis

Western blotting analyses were performed as previously described [35] using the following antibodies: anti-PML-RAR $\alpha$ (anti-RAR $\alpha$ (C20); sc-551 Santa Cruz Biotechnology), antiphospho-p44/42 MAPK (Erk1/2; \#9101, Cell Signalling Technology), anti-p44/42 MAPK (Erk1/2; \#9102, Cell Signalling Technology), antiphospho-p65 (NFkB p65, Ser 536; \#ab86299, Abcam), anti-p65 (NFkB p65; \#sc-8008 Santa Cruz Biotechnology) and anti- $\alpha$ Tubulin (\#T9026, Sigma). Goat anti-rabbit IgG, horseradish peroxidase conjugate (\#G21234) and goat antimouse IgG, horseradish peroxidase conjugate (\#G21040) were purchased from Thermo Fisher Scientific. Elaboration of images and densitometric analysis used ImageJ software (ImageJ 1.43u; National Institutes of Health, Bethesda, MD, USA). Data obtained by densitometric analysis of ERK1/2 phosphorylation were normalised to total ERK1/2 protein levels, while data from the analysis of p65 phosphorylation were normalised to total p65 protein levels.

\section{Results}

Effects of ELF-EMF on ATRA-dependent NB4 cells differentiation

We focused on ELF-EMF effects on differentiation driven by pharmacological doses of ATRA $\left(10^{-6} \mathrm{M}\right.$ - schematic representation reported in Fig. 1A). We found that ELF-EMF exposures decreased the number of NB4 cells in an intensitydependent manner (Fig. 1B). Significant fewer viable cells were monitored at both 1 and $2 \mathrm{mT}$ ELF-EMF intensities starting from 72 h of ATRA treatment. Remarkably, no significant differences were observed when NB4 cells were subjected to ELF-EMF exposure alone at any of the intensities tested (Fig. 1C). Further, the absence of evidence about the activation of the cell death process (evaluated as the number of live cells compared to total cells monitored by trypan blue dye exclusion assay - Fig. 1D), together with the lack of alterations to the shape of cells exposed to ATRA and ELF-EMF (data not shown), strongly suggested a possible effect of ELF-EMF on the ATRA-induced differentiation of APL cells. In the light of these results, all subsequent experiments were performed at the intensity of $2 \mathrm{mT}$. To assess the ATRA concentration that maximised the biological effects induced by ELF-EMF, ATRA dose-response experiments were performed for up to $96 \mathrm{~h}$ (Fig. 2). As shown in Fig. 2A, ATRA at a concentration of $10^{-6} \mathrm{M}$ proved to be the most effective dose reducing the number of cells by $33.1 \%( \pm 3.6 \%)$ compared to treatment with ATRA alone. The effect of ELF-EMF on ATRA-dependent differentiation was confirmed by measuring NBT reduction activity of NB4 cells (Fig. 2B). ATRA treatment at the concentration of $10^{-6}$

A
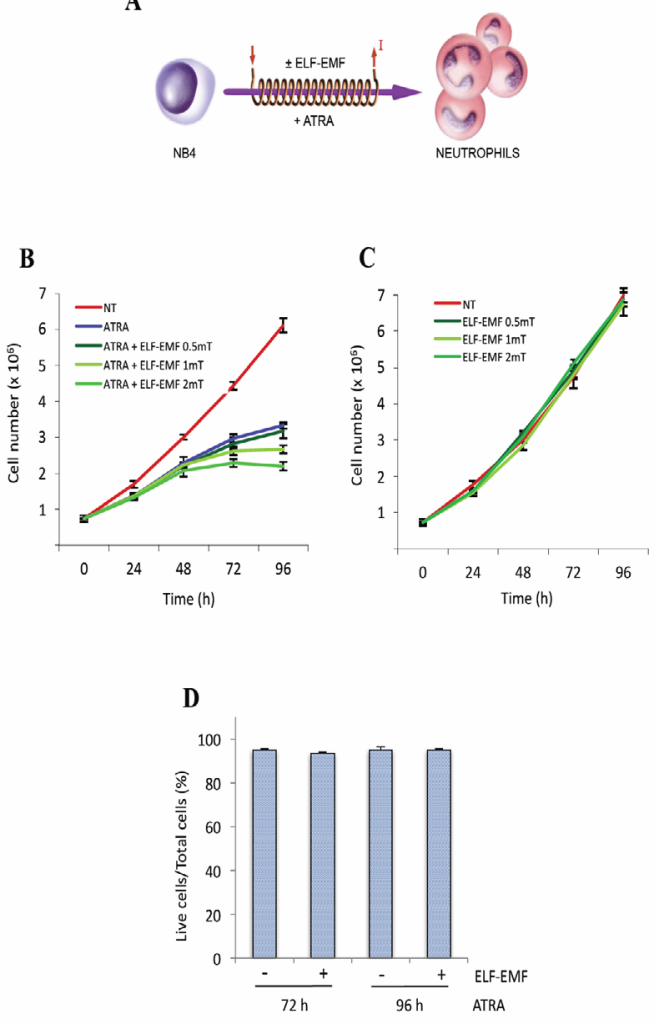

Fig. 1. Effects of ELF-EMF exposure on growth potential of ATRA-treated NB4 cells. (A) Schematic drawing of ATRA-mediated differentiation experiments on NB4 cells subjected to ELF-EMF exposure. (B-C) Growth curves of NB4 cells subjected to ATRA and ELF-EMF exposures (or to different intensities of ELF-EMF alone). Cells were treated with $1 \mu \mathrm{M}$ ATRA and grown up to $96 \mathrm{~h}$ with or without continuous ELF-EMF exposure at different intensities. Every 24 h, cell numbers were evaluated by TC10 automatic counter. The data show mean \pm SD from three indeysis of the ratio between viable cells and total cells previously exposed to ELF/EMF for 72 and $96 \mathrm{~h}$, in presence or in absence of ATRA. 


\section{Cellular Physiology Cell Physiol Biochem 2018;46:389-400

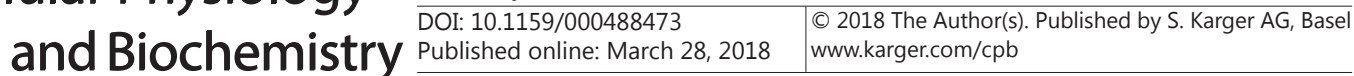 \\ Errico Provenzano et al.: ELF-EMFs Promote ATRA-Induced NB4 Cell Differentiation}

Fig. 2. Biological effects induced by different ATRA concentrations in combination with ELF-EMF ( $2 \mathrm{mT}$ ) on NB4 cells. Cells were exposed to ELF-EMF $2 \mathrm{mT} / 50 \mathrm{~Hz}$ for $96 \mathrm{~h}$ in combination with different concentrations of ATRA. (A) Evaluation of ATRA and ELF-EMF exposure effects on cellular growth. After treatments, cell viability was evaluated by TC10 automatic counter. The data show mean \pm SD resulting from three independent experiments. (B) Evaluation of NBT reduction ability of NB4 cells treated with ATRA at different concentrations and exposed or not exposed to ELF-EMF. The data show mean \pm SD from three independent experiments. ${ }^{*} \mathrm{P}<0.05$ vs. ATRA alonetreated cells by Student's t test.

M showed the greatest increase in NBT positive cells $(20.2 \% \pm 7.2 \%)$. Thus, $10^{-6} \mathrm{M}$ ATRA concentration was used in all following experiments.

Subsequently, ELF-EMF effects on changes of NBT reduction ability were measured at different time intervals during the $96 \mathrm{~h}$ of combined ELFEMF $(2 \mathrm{mT}) /$ ATRA $\left(10^{-6} \mathrm{M}\right)$ treatment. Compared to

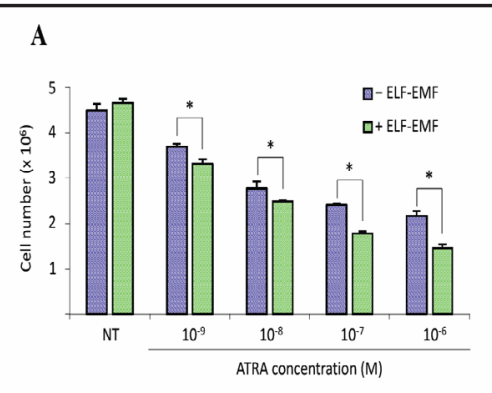

B

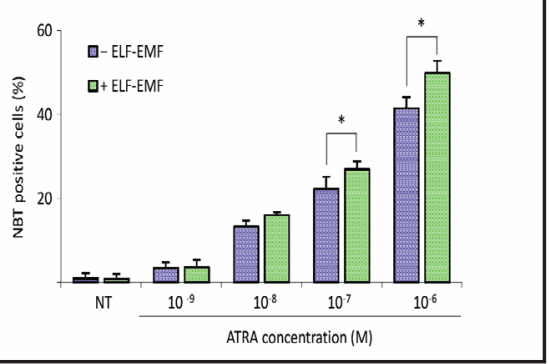
exposure to ATRA alone, ELF-EMF exposure caused an increase in the share of NBT positive cells at 72 and $96 \mathrm{~h}$ (Fig. 3A).

In addition, cellular morphology was evaluated to identify signs of differentiation. We performed May-Grünwald cell staining at $96 \mathrm{~h}$ of co-treatment, which showed a significant decrease in the nucleus/cytoplasm ratio compared to cells treated with ATRA alone (Fig. 3B).

Finally, to further determine the biological effects induced by ELF-EMF, we carried out a cytofluorimetric analysis of $\mathrm{CD} 11 \mathrm{~b}$ expression as a specific surface molecular marker of granulocytic differentiation, at 72 and $96 \mathrm{~h}$. A slight but significant increase of CD11b expressing cells was monitored at both time points with combined treatment (Fig. 3C and 3D). Flow-cytometric results were confirmed by a quantitative RT-qPCR assay that showed a clear increase of $1.8 \pm 0.4$ fold in the expression levels of CD11b at $96 \mathrm{~h}$ of co-treatment (Fig. 3E).

Role of ROS-ERK pathway in ELF-EMF promotion of ATRA-induced NB4 cells differentiation

ROS have been extensively proposed to mediate the effects of ELF-EMF in biological systems [36, 37]. To evaluate ROS involvement in ELF-EMF biological effects we measured intracellular ROS in DCFDA-loaded NB4 cells treated with ELF-EMF and ATRA. As shown in Fig. 4, DCF signal increased by about $44 \%$ after $8 \mathrm{~h}$ of exposure to ELF-EMF and persisted after $24 \mathrm{~h}$. ATRA-alone treatment did not induce significant variations. In the light of this result, we tested whether a ROS scavenger could limit the ELF-EMF effect on the differentiation of ATRA-treated NB4 cells. Cells were pre-treated for $1 \mathrm{~h}$ with $2.5 \mathrm{mM} \mathrm{N}$-acetylcysteine (NAC), then subjected to ATRA treatment and ELF-EMF exposure. When cells were pre-treated with NAC we observed a slight, although not significant, increase in the number of ATRA- and ELFEMF-exposed cells (Fig. 5A). Concomitantly, a significant reduction of CD11b positive cells was observed in NAC-treated cells at $72 \mathrm{~h}$ of exposure (Fig. 5B).

Then, we investigated the phosphorylation of ERK1/2 and the activation of NFKB signalling, which are known to be induced by the presence of ROS [38-40]. As shown in Fig. 6A, phosphorylation of ERK1/2 induced by ATRA is detectable starting from $8 \mathrm{~h}$ of treatment and progressively increases to peak after $16 \mathrm{~h}$. More interestingly, at $8 \mathrm{~h}$ ERK1/2 phosphorylation increased more than 2-fold in NB4 cells subjected to both ATRA and ELF-EMF exposure compared to ATRA-alone treated cells. The activation of NFKB signalling was investigated by 
analysing p65 phosphorylation. We found that, similarly to observations for ERK1/2, the phosphorylation of both proteins is enhanced by ATRA exposure at $8 \mathrm{~h}$ of treatment and decreases at 16 and 24 h. However, we could not find any difference between NB4 cells treated with both ATRA and ELF-EMF exposure and ATRA-alone treated cells (Fig. $6 \mathrm{~B})$.

To evaluate the possibility that ROS could mediate ELF-EMF effects by stabilising PMLRAR $\alpha$ [40], we analysed the PMLRAR $\alpha$ protein levels by immunoblotting. We did not find any significant alterations of PML-RAR $\alpha$ protein levels in ELF-EMF/ATRA exposed cells, compared with ATRA alone-treated cells. The ATRA-dependent protein degradation was already known and monitored without ELF-EMF after $24 \mathrm{~h}$ of treatment (Fig. 6A).

Fig. 4. Modulation of intracellular ROS levels by ELF-EMF exposure of NB4 cells. (A-C) ROS production was assessed by measuring the fluorescent intensity of DCF in NB4 cells untreated or treated with $1 \mu \mathrm{M}$ ATRA with or without a combined ELF-EMF exposure at $8 \mathrm{~h}$ (A), 16 $\mathrm{h}(\mathrm{B})$ and $24 \mathrm{~h}(\mathrm{C})$. Doxorubicin was used as a control for ROS generation. NT, untreated NB4 cells. (D) The incremental production of ROS was expressed as mean fluorescence ratio of ATRA/ELF-EMF and ATRA-treated cells. The data show mean \pm SD from three independent experiments. DOXO, doxorubicin-treated NB4 cells.
Fig. 3. Contribution of ELF-EMF exposure to ATRA-mediated cells. with to $96 \mathrm{~h}$ and or not exposed to ELFEMF $2 \mathrm{mT}$. After treatment, cell differentiation was assessed by evaluating NBT reducability (A), morchanges at Giemsa staining (scale $50 \mu \mathrm{m})(\mathrm{B}), \mathrm{CD} 11 \mathrm{~b}$ els (E). Data for (A), (C), (D) and (E) are mean \pm
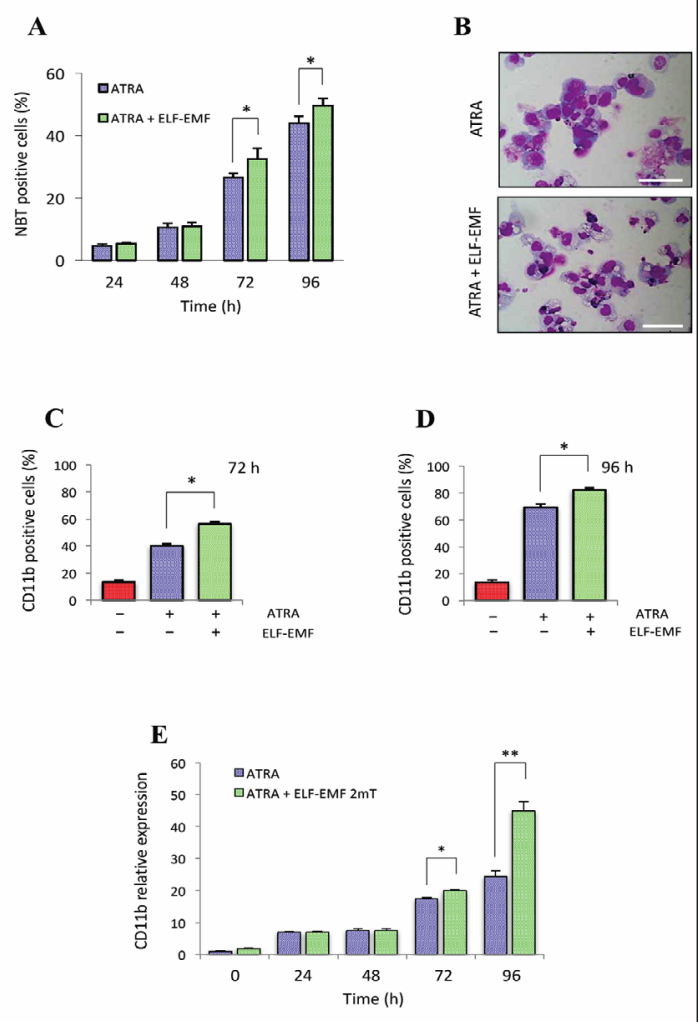

05 by Student's t test and ${ }^{* *} \mathrm{P}<0.01$ by Student's $\mathrm{t}$ test. 
$\begin{array}{lr}\text { ELF-EMF } & \text { effects } \\ \text { on } & \text { PMA-induced } \\ \text { differentiation of } & N B 4 \\ \text { cells } & \\ \text { While } & \text { assessing }\end{array}$

whether ELF-EMF activity on differentiation was specifically related to ATRAinduced NB4 cells, rather than to the differentiation process in general, the effects of ELF-EMF exposure were also investigated in phorbol 12-myristate 13-acetate (PMA) treated NB4 cells. PMA was chosen for its ability to change NB4 cells towards the monocytic lineage. Thus, the potential for cell proliferation, NBT reduction, morphological changes and CD14 expression were analysed (Fig. 7A-E).

NB4 cells subjected to combined treatment of ELFEMF/PMA showed a growth curve comparable to cells treated with PMA alone (Fig. 7A). To confirm this result we monitored NBT reduction activity during time-course experiments. As shown in Fig. 7B, no differences were observed for all the time points tested. Moreover, ELF-EMF/PMA treatments, compared to PMA alone, did not induce any increase in CD14 marker expression at either 72 or $96 \mathrm{~h}$ (Fig. 7C-D). In addition, morphology studies at $96 \mathrm{~h}$ of the combined treatment showed similar maturation to using PMA alone (Fig. 7E).

Following our previous results, we focused on ROS production and ERK1/2 activation. Interestingly, $8 \mathrm{~h}$ of ELF-EMF/PMA combined treatments did not increase ROS levels when compared to PMA alone (Fig. 7F). Likewise, ERK1/2 activation was the same in both ELFEMF/PMA and PMA alone-treated NB4 cells (Fig. 7G).

\section{Discussion}

ELF-EMF is proven to affect differentiation in murine and human cells of different origins [3, 41-44]. The exposure to extremely low frequency ELF-EMF (50 Hz) induced more rapid maturation and differentiation in neural cells. These included rat immature cerebellar granule neurons and mouse embryonic neural stem cells $[3,41]$, as well as mouse pituitary corticotrope-derived cells [42]. Similar results were obtained in human cardiac stem cells derived from human myocardial bioptic specimens, where differentiation toward a cardiacspecific phenotype was observed after exposure to low-frequency EMF [43]. Interestingly,

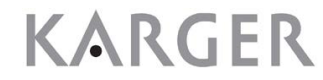




\section{Cellular Physiology Cell Physiol Biochem 2018;46:389-400 \begin{tabular}{l|l} 
DOI: 10.1159/000488473 & and Biochemistry \\
Published online: March 28, 2018 & $\begin{array}{l}\text { O 2018 The Author(s). Published by S. Karger AG, Basel } \\
\text { www.karger.com/cpb }\end{array}$
\end{tabular} \\ Errico Provenzano et al.: ELF-EMFs Promote ATRA-Induced NB4 Cell Differentiation}

Fig. 7. Contribution of ELF-EMF exposure to PMA-mediated NB4 cellular maturation. (A-E) Time-course experiments on PMA-treated NB4 cells. Cells were treated with 0.16 nM PMA for up to $96 \mathrm{~h}$ and exposed or not exposed to ELF-EMF (2 mT). After treatments, cell differentiation was evaluated through cell viability (A), NBT reduction ability (B), CD14 marker expression at $72 \mathrm{~h}$ (C) and $96 \mathrm{~h}$ (D) and morphological changes at $96 \mathrm{~h}$ by May-Grünwald-Giemsa staining (E) (scale bar: $50 \mu \mathrm{m}$ ). (F) ROS production was assessed by measuring the fluorescent intensity of DCF in NB4 cells treated with $0.16 \mathrm{nM}$ PMA with or without a combined ELF-EMF exposure for $8 \mathrm{~h}$. Data for (A), (B), (C) and (D) show mean \pm SD from three independent experiments. NT, untreated NB4 cells. (G) Effects of ELF-EMF exposure on ERK1/2 phosphorylation of PMA-treated NB4 cells. Total cell lysates were analyzed by western blot for the proteins indicated. NT, untreated NB4 cells lysate.
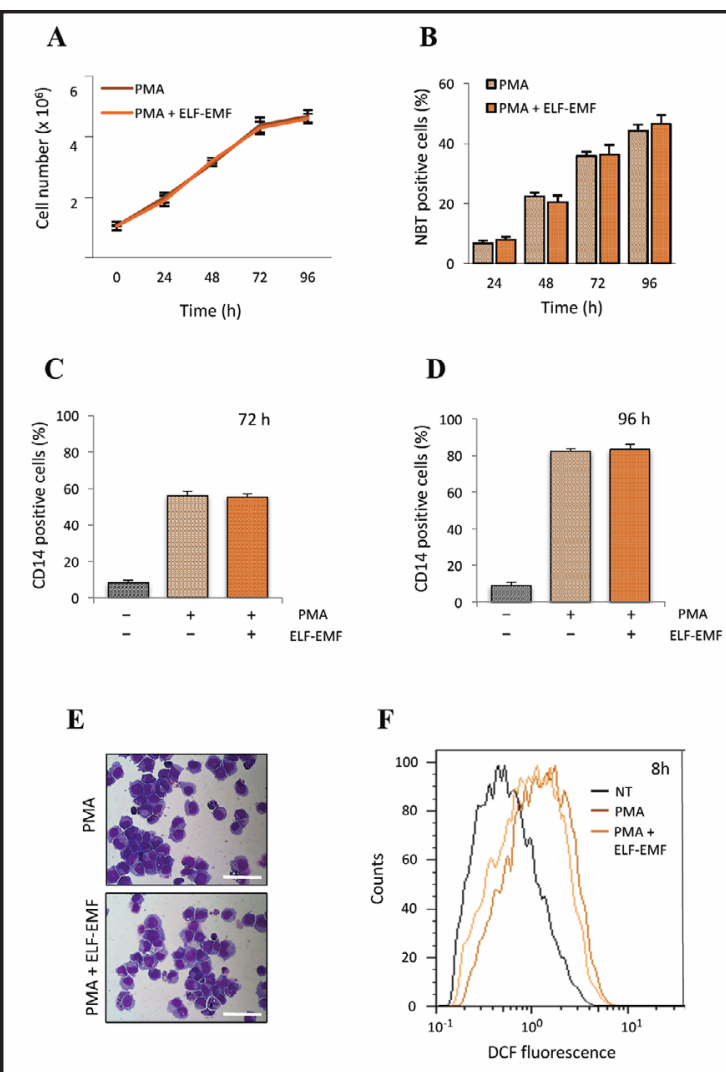

G

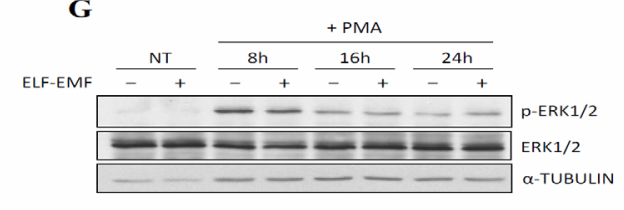

ELF-EMF exposure was recently seen to promote differentiation also in human cells from hematopoietic malignancies, such as the myelogenous leukemia cell line K562 [44].

Since the 1980s, the concept of differentiation therapy has been regarded as a novel promising approach for the treatment of acute promyelocytic leukemia (APL) [45]. ATRA induces differentiation in APL patient samples [46] and its use in combination with chemotherapy is the currently accepted treatment for APL. This could be a paradigm for differentiation therapy in clinical oncology $[45,47]$.

In this research, we sought to determine whether ELF-EMF exposure could affect the differentiation process of ATRA-stimulated NB4 cells.

Our results indicate that ELF-EMFs promote ATRA-induced NB4 cells differentiation that varies with the dose. After $96 \mathrm{~h}$ of exposure at $2 \mathrm{mT}$ the number of cells is about one third lower compared to cells treated with ATRA alone without detectable signs of cell death. Most importantly, the lower cell number count was paralleled by an increase in known granulocytic differentiation markers, such as NBT reduction activity and CD11b surface marker expression.

ROS have been tentatively proposed to mediate the effects of ELF-EMF [36, 37]. Thus, while investigating mechanisms underlying the effects observed in NB4 cells, we monitored ROS levels in ELF-EMF-irradiated and ATRA-treated cells. Interestingly, a significant increase in ROS levels was observed shortly after exposure to ELF-EMF. However, the precise mechanisms through which ELF-EMF increases cellular ROS production remain unknown. Likewise, we cannot speculate which specific ROS mediated the ELF-EMF effects, as 
dichlorofluorescein can detect a broad array of reactive intermediates [48]. This observation drove us to see if the observed increment of ROS was associated with the activation of downstream molecular events that could promote cell differentiation. ROS can activate the ERK pathway in different cell types [49] and events such as the activation of ERK1/2, via phosphorylation, play a functional role in regulating differentiation [50-52]. Similarly, ROS exposure has been associated with the activation of NF- $\kappa$ B pathway [53], whose role in differentiation has been shown in several tissues and cells [54,55], including granulocytes [56]. Our data show that ELF-EMF induced an increased phosphorylation level of ERK1/2 but not of p65 proteins, suggesting a possible role of the ERK pathway in differentiation driven by ELF-EMF, but not the involvement of NF-אB signalling. However, further studies will be necessary to determine the role of the ERK pathway and other mechanisms may be involved in the ELF-EMF promotion of ATRA-induced NB4 maturation.

To gain further insight into the role of ROS in ELF-EMF activity, we inhibited ROS accumulation by the ROS scavenger NAC and then monitored the effect on differentiation. NAC treatment induced an increase of cell number, although not significant, and, more importantly, a reduction of CD11b expression after $72 \mathrm{~h}$ of exposure. To provide continuous NAC exposure, with longer treatments, we repeated NAC treatments every $24 \mathrm{~h}$ observing, unfortunately, toxicity at both 72 and $96 \mathrm{~h}$ (data not shown).

Finally, we demonstrated that ELF-EMF activity is related to ATRA-induced differentiation, as PMA-treated NB4 cells did not show significant modulation in the monocytic maturation process. Compared to PMA alone, combined ELF-EMF/PMA treatments did not cause increases in either ROS cellular levels or ERK1/2 proteins phosphorylation. Since PMAtreated NB4 cells showed an early induction of ROS, it is reasonable to hypothesise that this phenomenon could impair the ROS increment mediated by ELF-EMF and the consequent enhanced ERK1/2 phosphorylation observed in ELF-EMF/ATRA treated NB4 cells.

In conclusion, the data indicate that ELF-EMF exposure promotes ATRA-induced differentiation in APL NB4 cells and suggest the possible involvement of ROS and ERK signalling pathway in this phenomenon. Although further studies will be necessary to evaluate the potential effects of ELF-EMF exposure on differentiation processes and to further detail the mechanism of action, these results offer interesting suggestions for future clinical implications.

\section{Abbreviations}

APL (Acute Promyelocytic Leukemia); AML (Acute Myeloid leukemia); NB4 (cell line derived by APL patient); PML/RAR $\alpha$ (Promyelocytic Leukemia protein - PML / Retinoic Acid Receptor alpha - RAR $\alpha$ fusion protein); ELF-EMFs (extremely low-frequency electromagnetic fields); ATRA (all-trans retinoic acid); PMA (phorbol 12-myristate 13-acetate); ERK1/2 (extracellular signal-regulated kinases); DCFDA (2',7'-dichlorofluorescein diacetate); NBT (nitroblue tetrazolium); ROS (reactive oxygen species); NAC (N-acetylcysteine).

\section{Acknowledgements}

This work was partially supported by a grant of the Department of Biomolecular Science (University of Urbino) - "Progetto di Valorizzazione 2017" - and by the Associazione a Sostegno degli Studi Oncologici (A.S.S.O.). We thank Dr. Timothy JB Wills for the assistance with the English revision of the manuscript.

\section{Disclosure Statement}

The authors declare no competing financial interests.

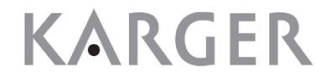




\section{Cellular Physiology Cell Physiol Biochem 2018;46:389-400

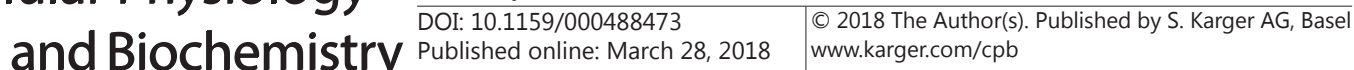 \\ Errico Provenzano et al.: ELF-EMFs Promote ATRA-Induced NB4 Cell Differentiation}

\section{References}

1 Lacy-Hulbert A, Metcalfe JC, Hesketh R: Biological responses to electromagnetic fields. FASEB J 1998;12:395-420.

-2 Sun ZC, Ge JL, Guo B, Guo J, Hao M, Wu YC, Lin YA, La T, Yao PT, Mei YA, Feng Y, Xue L: Extremely low frequency electromagnetic fields facilitate vesicle endocytosis by increasing presynaptic calcium channel expression at a central synapse. Sci Rep 2016;6:21774.

3 Ma Q, Chen C, Deng P, Zhu G, Lin M, Zhang L, Xu S, He M, Lu Y, Duan W, Pi H, Cao Z, Pei L, Li M, Liu C, Zhang Y, Zhong M, Zhou Z, Yu Z: Extremely low-frequency electromagnetic fields promote in vitro neuronal differentiation and neurite outgrowth of embryonic neural stem cells via up-regulating TRPC1. PLoS One 2016; DOI 10.1371/journal.pone.0150923.

4 Wolf FI, Torsello A, Tedesco B, Fasanella S, Boninsegna A, D’Ascenzo M, Grassi C, Azzena GB, Cittadini A: 50$\mathrm{Hz}$ extremely low frequency electromagnetic fields enhance cell proliferation and DNA damage: possible involvement of a redox mechanism. Biochim Biophys Acta 2005;1743:120-129.

5 Baek S, Quan X, Kim S, Lengner C, Park JK, Kim J: Electromagnetic fields mediate efficient cell reprogramming into a pluripotent state. ACS Nano 2014;8:10125-1038.

6 Simkó M, Mattsson MO: Extremely low frequency electromagnetic fields as effectors of cellular responses in vitro: possible immune cell activation. J Cell Biochem 2004;93:83-92.

7 Linet MS, Hatch EE, Kleinerman RA, Robison LL, Kaune WT, Friedman DR, Severson RK, Haines CM, Hartsock CT, Niwa S, Wacholder S, Tarone RE: Residential exposure to magnetic fields and acute lymphoblastic leukemia in children. N Engl J Med 1997;337:1-7.

-8 Green LM, Miller AB, Villeneuve PJ, Agnew DA, Greenberg ML, Li J, Donnelly KE: A case-control study of childhood leukemia in southern Ontario, Canada, and exposure to magnetic fields in residences. Int J Cancer 1999;82:161-170.

-9 Ahlbom IC, Cardis E, Green A, Linet M, Savitz D, Swerdlow A, ICNIRP (International Commission for Non-Ionizing Radiation Protection) Standing Committee on Epidemiology: Review of the epidemiologic literature on EMF and Health. Environ Health Perspect 2001;109:911-933.

10 Fam WZ, Mikhail EL: Lymphoma induced in mice chronically exposed to very strong low-frequency electromagnetic field. Cancer Lett 1996;105:257-269.

-11 Boorman GA, McCormick DL, Ward JM, Haseman JK, Sills RC: Magnetic fields and mammary cancer in rodents: a critical review and evaluation of published literature. Radiat Res 2000;153:617-626.

12 De Mattei M, Caruso A, Traina GC, Pezzetti F, Baroni T, Sollazzo V: Correlation between pulsed electromagnetic fields exposure time and cell proliferation increase in human osteosarcoma cell lines and human normal osteoblast cells in vitro. Bioelectromagnetics 1999;20:177-182.

13 Ruiz Gómez MJ, De la Peña L, Pastor JM, Martínez Morillo M, Gil L: 25 Hz electromagnetic field exposure has no effect on cell cycle distribution and apoptosis in U-937 and HCA-2/1cch cells. Bioelectrochemistry 2001;53:137-140.

14 Simkó M, Kriehuber R, Weiss DG, Luben RA: Effects of $50 \mathrm{~Hz}$ EMF exposure on micronucleus formation and apoptosis in transformed and nontransformed human cell lines. Bioelectromagnetics 1998;19:85-91.

15 McLeod KJ, Collazo L: Suppression of a differentiation response in MC-3T3-E1 osteoblast-like cells by sustained, low-level, $30 \mathrm{~Hz}$ magnetic-field exposure. Radiat Res 2000;153:706-714.

16 McCann J, Dietrich F, Rafferty C: The genotoxic potential of electric and magnetic fields: an update. Mutat Res 1998;411:45-86.

17 Phillips JL, Haggren W, Thomas WJ, Ishida JT, Adey WR: Magnetic field-induced changes in specific gene transcription. Biochim Biophys Acta 1992;1132:140-144.

18 Morehouse CA, Owen RD: Exposure of Daudi cells to low-frequency magnetic fields does not elevate MYC steady-state mRNA levels. Radiat Res 2000;153:663-669.

19 Zhou J, Li C, Yao G, Chiang H, Chang Z: Gene expression of cytokine receptors in HL60 cells exposed to a 50 Hz magnetic field. Bioelectromagnetics 2002;23:339-346.

20 Stoner GD, Wang LS, Casto BC: Laboratory and clinical studies of cancer chemoprevention by antioxidants in berries. Carcinogenesis 2008;29:1665-1674. 


\section{Cellular Physiology Cell Physiol Biochem 2018;46:389-400 \begin{tabular}{c|c|c|} 
DOI: 10.1159/000488473 & and Biochemistry Published online: Narch 28, 2018 & $\begin{array}{l}\text { O } 2018 \text { The Author(s). Published by S. Karger AG, Basel } \\
\text { www.karger.com/cpb }\end{array}$ \\
\hline
\end{tabular} \\ Errico Provenzano et al.: ELF-EMFs Promote ATRA-Induced NB4 Cell Differentiation}

-21 Reth M: Hydrogen peroxide as second messenger in lymphocyte activation. Nat Immunol 2002;3:11291134.

-22 Forman HJ: Use and abuse of exogenous $\mathrm{H}_{2} \mathrm{O}_{2}$ in studies of signal transduction. Free Radic Biol Med 2007;42:926-932.

23 Teepen JC, van Dijck JA: Impact of high electromagnetic field levels on childhood leukemia incidence. Int J Cancer 2012;131:769-778.

-24 Brain JD, Kavet R, McCormick DL, Poole C, Silverman LB, Smith TJ, Valberg PA, Van Etten RA, Weaver JC: Childhood leukemia: electric and magnetic fields as possible risk factors. Environ Health Perspect 2003;111:962-970.

25 Mi JQ, Li JM, Shen ZX, Chen SJ, Chen Z: How to manage acute promyelocytic leukemia. Leukemia 2012;26:1743-1751.

26 Shima Y, Honma Y, Kitabayashi I: PML-RAR $\alpha$ and its phosphorylation regulate PML oligomerization and HIPK2 stability. Cancer Res 2013;73:4278-4288.

27 Dermime S, Grignani F, Clerici M, Nervi C, Sozzi G, Talamo GP, Marchesi E, Formelli F, Parmiani G, Pelicci PG, Gambacorti-Passerini C: Occurrence of resistance to retinoic acid in the acute promyelocytic leukemia cell line NB4 is associated with altered expression of the PML/RAR alpha protein. Blood 1993;82:1573-1577.

28 Nasr R, Lallemand-Breitenbach V, Zhu J, Guillemin MC, de Thé H: Therapy-induced PML/RARA proteolysis and acute promyelocytic leukemia cure. Clin Cancer Res 2009;15:6321-6326.

29 Grignani F, De Matteis S, Nervi C, Tomassoni L, Gelmetti V, Cioce M, Fanelli M, Ruthardt M, Ferrara FF, Zamir I, Seiser C, Grignani F, Lazar MA, Minucci S, Pelicci PG: Fusion proteins of the retinoic acid receptor-alpha recruit histone deacetylase in promyelocytic leukaemia. Nature 1998;391:815-818.

-30 Di Croce L, Raker VA, Corsaro M, Fazi F, Fanelli M, Faretta M, Fuks F, Lo Coco F, Kouzarides T, Nervi C, Minucci S, Pelicci PG: Methyltransferase recruitment and DNA hypermethylation of target promoters by an oncogenic transcription factor. Science 2002;295:1079-1082.

-31 Amatori S, Bagaloni I, Macedi E, Formica M, Giorgi L, Fusi V, Fanelli M: Malten, a new synthetic molecule showing in vitro antiproliferative activity against tumour cells and induction of complex DNA structural alterations. Br J Cancer 2010;103:239-248.

-32 Amatori S, Papalini F, Lazzarini R, Donati B, Bagaloni I, Rippo MR, Procopio A, Pelicci PG, Catalano A, Fanelli M: Decitabine, differently from DNMT1 silencing, exerts its antiproliferative activity through p21 upregulation in malignant pleural mesothelioma (MPM) cells. Lung Cancer 2009;66:184-190.

-33 Villa R, Pasini D, Gutierrez A, Morey L, Occhionorelli M, Viré E, Nomdedeu JF, Jenuwein T, Pelicci PG, Minucci S, Fuks F, Helin K, Di Croce L: Role of the polycomb repressive complex 2 in acute promyelocytic leukemia. Cancer Cell 2007;11:513-525.

-34 Guerzoni C, Amatori S, Giorgi L, Manara MC, Landuzzi L, Lollini PL, Tassoni A, Balducci M, Manfrini M, Pratelli L, Serra M, Picci P, Magnani M, Fusi V, Fanelli M, Scotlandi K. An aza-macrocycle containing maltolic side-arms (maltonis) as potential drug against human pediatric sarcomas. BMC Cancer 2014;14:137.

-35 Amatori S, Mazzoni L, Alvarez-Suarez JM, Giampieri F, Gasparrini M, Forbes-Hernendez TY, Afrin S, Errico Provenzano A, Persico G, Mezzetti B, Amici A, Fanelli M, Battino M. Polyphenol-rich strawberry extract (PRSE) shows in vitro and in vivo biological activity against invasive breast cancer cells. Sci Rep 2016;6:30917

36 Katsir G, Parola AH: Enhanced proliferation caused by a low frequency weak magnetic field in chick embryo fibroblasts is suppressed by radical scavengers. Biochem Biophys Res Commun 1998;252:753756.

-37 Morabito C, Guarnieri S, Fanò G, Mariggiò MA: Effects of acute and chronic low frequency electromagnetic field exposure on PC12 cells during neuronal differentiation. Cell Physiol Biochem 2010;26:947-958.

38 Dayem AA, Choi HY, Kim JH, Cho SG: Role of oxidative stress in stem, cancer, and cancer stem cells. Cancers (Basel) 2010;2:859-884.

-39 Kapri-Pardes E, Hanoch T, Maik-Rachline G, Murbach M, Bounds PL, Kuster N, Seger R: Activation of signaling cascades by weak extremely low frequency electromagnetic fields. Cell Physiol Biochem 2017;43:1533-1546.

-40 Cao Y, Wei W, Zhang N, Yu Q, Xu WB, Yu WJ, Chen GQ, Wu YL, Yan H: Oridonin stabilizes retinoic acid receptor alpha through ROS-activated NF-kB signalling. BMC Cancer 2015;15:248-259.1 


\section{Cellular Physiology Cell Physiol Biochem 2018;46:389-400

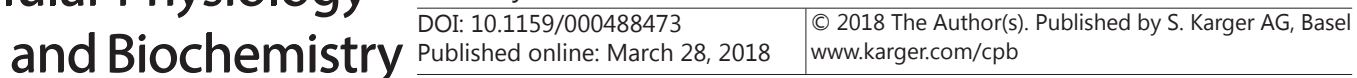 \\ Errico Provenzano et al.: ELF-EMFs Promote ATRA-Induced NB4 Cell Differentiation}

41 Lisi A, Ciotti MT, Ledda M, Pieri M, Zona C, Mercanti D, Rieti S, Giuliani L, Grimaldi S: Exposure to $50 \mathrm{~Hz}$ electromagnetic radiation promote early maturation and differentiation in newborn rat cerebellar granule neurons. J Cell Physiol 2005;204:532-538.

42 Lisi A, Ledda M, Rosola E, Pozzi D, D’Emilia E, Giuliani L, Foletti A, Modesti A, Morris SJ, Grimaldi S: Extremely low frequency electromagnetic field exposure promotes differentiation of pituitary corticotropederived AtT20 D16V cells. Bioelectromagnetics 2006;27:641-651.

43 Gaetani R, Ledda M, Barile L, Chimenti I, De Carlo F, Forte E, Ionta V, Giuliani L, D’Emilia E, Frati G, Miraldi F, Pozzi D, Messina E, Grimaldi S, Giacomello A, Lisi A: Differentiation of human adult cardiac stem cells exposed to extremely low-frequency electromagnetic fields. Cardiovasc Res 2009;82:411-420.

-44 Ayșe IG, Zafer A, Sule O, Işil IT, Kalkan T: Differentiation of K562 cells under ELF-EMF applied at different time courses. Electromagn Biol Med 2010;29:122-130.

45 Petrie K, Zelent A, Waxman S: Differentiation therapy of acute myeloid leukemia: past, present and future. Curr Opin Hematol 2009;16:84-91.

-46 Breitman TR, Collins SJ, Keene BR: Terminal differentiation of human promyelocytic leukemic cells in primary culture in response to retinoic acid. Blood 1981;57:1000-1004.

47 Mandelli F, Diverio D, Avvisati G, Luciano A, Barbui T, Bernasconi C, Broccia G, Cerri R, Falda M, Fioritoni G, Leoni F, Liso V, Petti MC, Rodeghiero F, Saglio G, Vegna ML, Visani G, Jehn U, Willemze R, Muus P, Pelicci PG, Biondi A, Lo Coco F: Molecular remission in PML/RAR alpha-positive acute promyelocytic leukemia by combined all-trans retinoic acid and idarubicin (AIDA) therapy. Blood 1997;90:1014-1021.

-48 LeBel CP, Ischiropoulos H, Bondy SC: Evaluation of the probe 2',7'-dichlorofluorescin as an indicator of reactive oxygen species formation and oxidative stress. Chem Res Toxicol 1992;5:227-231.

49 Thannickal VJ, Fanburg BL: Reactive oxygen species in cell signaling. Am J Physiol Lung Cell Mol Physiol 2000;279:L1005-1028.

50 Scholl C, Gilliland DG, Fröhling S: Deregulation of signaling pathways in acute myeloid leukemia. Semin Oncol. 2008;35:336-345.

51 Licht JD, Zelent A: Retinoid and growth factor receptor signalling in APL. Blood 2005;105:1381-1382.

52 Schenk T, Stengel S, Zelent A: Unlocking the potential of retinoic acid in anticancer therapy. Br J Cancer 2014;111:2039-2045.

53 Morgan MJ, Liu Z: Crosstalk of reactive oxygen species and NF- $\kappa$ B signalling. Cell Res 2011;21:103-115

54 Baeza-Raja B, Munoz-Canoves P: p38 MAPK-induced nuclear factor-kappaB activity is required for skeletal muscle differentiation: role of interleukin-6. Mol Biol Cell 2004;15:2013-2026.

55 Mattson MP: NF-kappaB in the survival and plasticity of neurons. Neurochem Res 2005;30:883-893.

56 Bottero V, Withoff S, Verma IM: NF-kappaB and the regulation of hematopoiesis. Cell Death Differ 2006;13:785-797. 